\title{
KEPEMIMPINAN DAN KINERJA PIMPINAN PEREMPUAN
}

\author{
Wirasandi $^{1}$, Hary Murcahyanto ${ }^{2}$, Mawardi ${ }^{3}$, Abdul Majid Junaidi ${ }^{4}$, Rasyid \\ Ridho Hamidy ${ }^{5}$ \\ Universitas Gunung Rinjani ${ }^{1,3,4,5}$, UniversitasHamzanwadi ${ }^{2}$, \\ harymurcahyanto@gmail.com²
}

\begin{abstract}
ABSTRAK
Penelitian ini bertujuan untuk mengetahui kinerja kepala desa dan lurah perempuan dalam melaksanakan tugas-tugas, untuk mengetahui persepsi para tokoh, staf desa, dan masyarakat tiga desa dan satu kelurahan di Kabupaten Lombok Timur tentang kinerja kepala desa dan lurah perempuan dan untuk mengetahui tantangan dan hambatan yang dihadapi dalam melaksanakan kepemimpinannya. Dengan adanya penyetaraan gender perempuan saat ini tidak hanya bekerja di wilayah domestik namun banyak yang bekerja di wilayah publik menjadi pemimpin seperti halnya yang berada di tiga desa dan satu kelurahan di wilayah Kabupaten Lombok Timur yang dipimpin oleh seorang perempuan. Penelitian ini menggunakan metode kualitatif dengan pendekatan studi kasus yang berlokasi di empat lokasi di Kabupaten Lombok Timur. Subjek penelitian ini adalah staf pemerintahan desa, kepala desa/lurah, masyarakat, tokoh agama, tokoh adat dan tokoh masyarakat di tiga desa dan satu kelurahan di wilayah Kabupaten Lombok Timur. Jenis data dan sumber data yakni data primer dan sekunder. Teknik pengumpulan data menggunakan teknik purposive sampling. Metode pengumpulan data menggunakan observasi, wawancara dan dokumentasi. Analisis data yaitu reduksi data, penyajian data dan penarikan kesimpulan. Uji keabsahan data dengan memperdalam pengamatan, in dept interview dan triangulasi. Hasil penelitian penelitian menunjukan bahwa kinerja kepala desa perempuan adalah kinerja yang bagus, disiplin bertanggung jawab dan tidak pernah menunda-nunda tugasnya. Serta pemerataan pembangunan terus-menerus dilaksanakan sesuai dengan program yang telah dijalankan. Hal ini diakui oleh staf desa dan masyarakat di tiga desa Kabupaten Lombok Timur. Persepsi masyarakat terhadap kinerja kepala desa/lurah perempuan, bahwa kinerja kepala desa/lurah perempuan cukup bagus apabila dibandingkan dengan kinerja kepala desa/lurah pria. Kepala desa perempuan memiliki partisipasi yang tinggi, sering memberikan contoh maupun mengajak masyarakat dalam bergotong-royong dan menjadikan desa yang dipimpinnya lebih maju. Tantangan dan hambatan yang dihadapi kepala desa perempuan yakni ketika mengurus rumah tangganya. Selain menjadi pemimpin di desanya juga menjadi seorang ibu rumah tangga yang harus bisa membagi waktu antara pekerjaan rumah tangga dengan pekerjaan dinasnya.
\end{abstract}

Kata Kunci: Kepemimpinan, kinerja, perempuan

\section{ABSTRACT}

This study aims to determine the performance of female village heads and lurah in carrying out their duties, to find out the perceptions of leaders, village staff, 
and the community of three villages and one kelurahan in Lombok Timur Regency about the performance of female village heads and lurah and to find out the challenges and obstacles. faced in carrying out their leadership. With the existence of gender equality, women currently do not only work in the domestic area, but many who work in the public area become leaders, such as those in three villages and one kelurahan in Lombok Timur Regency which are led by a woman. This research uses a qualitative method with a case study approach located in four villages in Lombok Timur Regency. The subjects of this research are village government staff, village heads/lurah, community, religious leaders, traditional leaders, and community leaders in three villages and one kelurahan in Lombok Timur Regency. The types of data and data sources are primary and secondary data. The data collection technique used the purposive sampling technique. Methods of data collection using observation, interviews, and documentation. Data analysis is data reduction, data presentation, and conclusion drawing. Test the validity of the data by deepening observations, indepth interviews, and triangulation. The results of the research showed that the performance of the female village head was good, responsible discipline, and never procrastinating on her duties. And the distribution of development is continuously carried out following the programs that have been implemented. This was acknowledged by village staff and communities in three villages in Lombok Timur Regency. The community's perception of the performance of the female village head/lurah is that the performance of the female village head/lurah is quite good when compared to the performance of the male village head/lurah. Female village heads have high participation, often provide examples, and invite the community to work together and make the village they lead more advanced. The challenges and obstacles faced by female village heads are when taking care of their household. In addition to being a leader in her village, she is also a housewife who must be able to divide her time between household work and her official work.

Keywords: leadership, performance,women

\section{PENDAHULUAN}

Kabupaten Lombok Timur memiliki luas 1.230,76 $\mathrm{Km}^{2}$ terdiri dari 20 kecamatan, 15 kelurahan dan 239 desa. Dari 15 Kelurahan dan 239 desa tersebut beberapa kelurahan dan desa dipimpin oleh seorang perempuan, diantaranya adalah Desa Rarang Batas Kecamatan Terara, Desa Labuhan Lombok Kecamatan Pringgabaya, Desa Dadap Kecamatan Sambelia, dan Kelurahan Selong Kecamatan Selong. (data Statistik kabupaten Lombok Timur 2018).

Desa dan Kelurahan adalah suatu organisasi atau lembaga yang memiliki wilayah administratif di bawah kecamatan. Desa dipimpin oleh seorang kepala desa bukan pegawai negeri sedangkan kelurahan dipimpin oleh seorang lurah berstatus sebagai pegawai negri atau Aparatur Sipil Negara(ASN). Keberhasilan suatu organisasi atau lembaga baik secara keseluruhan maupun kelompok dalam suatu organisasi tertentu sangat tergantung pada mutu kepemimpinan yang terdapat dalam suatu organisasi yang bersangkutan (Alvesson, 2012; A. L. Davis et al., 2020; R. Davis \& Cates, 2018; Frost et al., 1985; Way et al., 2007). Konsep kepemimpinan pada dasarnya berasal dari kata "pimpin yang artinya bimbing dan 
tuntun. Dari kata "pimpin" melahirkan kata kerja "memimpin" yaitu orang yang berfungsi memimpin atau orang yang membimbing atau menuntun.(Bennis, 1959; Horner, 1997; Lussier \& Achua, 2015; Nohria \& Khurana, 2010; Underdal, 1994; Van Seters \& Field, 1990). Sedangkan kepemimpinan yaitu kemampuan seseorang dalam mempengaruhi orang lain dalam mencapai tujuan (Murcahyanto \& Asmawi, 2019; Purnomo \& Subari, 2019). Di dalam kehidupan sehari-hari dan berbagai literatur yang membahas kepemimpinan muncul istilah yang hampir sama dengan istilah yang hampir sama dengan hal tersebut dan kadang-kadang dipergunakan silih berganti seolah-olah tidak ada perbedaan satu dengan yang lainya, yaitu "pimpinan" dan pemimpin" (Pasolong, 2008).

Kemampuan dalam memimpin antara laki-laki dan perempuan tentu berbeda-beda. Kepemimpinan identik dengan laki-laki jika dilihat dari ideologi kita yang patriarki ini.(Sahrah, 2004). Struktur sosial dalam masyarakat masih menjadikan pemimpin laki-laki lebih memegang peranan penting dalam sektor publik dibandingkan pemimpin perempuan.(Fitriani, 2015). Pemimpin laki-laki lebih sering dianggap mempunyai status yang lebih tinggi dari perempuan.(Handriana \& Basuki, 2012). Seperti yang ada di Negara Indonesia lebih banyak pemimpin laki-laki dibandingkan pemimpin perempuan. Namun keberhasilan kepemimpinan perempuan dalam pemerintahan Desa-Desa atau Desa-Desa di Kabupaten Lombok Timur masih dipertanyakan. Munculnya perempuan sebagai pemimpin di suatu daerah yang masih budaya patriarki merupakan suatu realitas yang menarik bagi peneliti untuk mengungkapkan.

Penelitian tentang kepemimpinan perempuan sudah banyak dilaksanakan antara lain, (Novianti, 2008) tentang Dilema Kepemimpinan Perempuan Dalam Islam, (Situmorang, 2011) tentang Gaya Kepemimpinan Perempuan, (Fitriani, 2015) tentang Gaya Kepemimpinan Perempuan, dan lain sebagainya. Yang membedakan penelitian ini dengan penelitian sebelumnya adalah tentang tantangan dan hambatan kepemimpinan perempuan dalam pemerintahan khususnya pada tingkat desa. Perbedaan penelitian ini adalah menganalisis tiga desa dan satu kelurahan di wilayah Kabupaten Lombok Timur yang dipimpin oleh seorang perempuan. Berdasarkan latar belakang di atas maka peneliti tertarik untuk meneliti masalah tersebut.

\section{METODE PENELITIAN}

Jenis penelitian ini adalah penelitian kualitatif. Penelitian kualitatif merupakan prosedur penelitian yang menghasilkan data deskriptif berupa datadata tertulis atau lisan dari orang- orang dan perilaku yang diamati. Dalam metode penelitian kualitatif metode yang biasanya dimanfaatkan adalah wawancara, pengamatan, dan pemanfaatan dokumen. (Moleong, 2019; Sugiono, 2017; Sugiyono, 2012). Sedangkan Penelitian ini menggunakan pendekatan studi kasus dengan menggunakan gejala atau fenomena yang berkaitan dengan perilaku karakter seseorang, Bila kita melakukan penelitian yang rinci tentang seseorang (individu) atau sesuatu unit sosial selama kurun waktu tertentu, kita melakukan apa yang disebut studi kasus. Lokasi penelitian, Penelitian dilakukan di Desa Rarang Batas Kecamatan Terara, Desa Labuhan Lombok Kecamatan Pringgabaya, Desa Dadap Kecamatan Sambelia, dan Kelurahan Selong Kecamatan Selong Kabupaten Lombok. 


\section{HASIL DAN PEMBAHASAN}

\section{Kinerja Kepala Desa dan Lurah Perempuan Di Kabupaten Lombok Timur}

Kabupaten Lombok Timur terdiri dari 20 kecamatan, 15 kelurahan dan 239 desa. Dari seluruh desa dan kelurahan tersebut diantaranya dipimpin oleh seorang perempuan yakni Desa Rarang Batas Kecamatan Terara dipimpin oleh Ibu Samiah, Desa Labuhan Lombok Kecamatan Pringgabaya dipimpin oleh Ibu Siti Zainab, Desa Dadap Kecamatan Sambelia dipimpin oleh Ibu Rohani , dan Kelurahan Selong Kecamatan Selong dipimpin oleh Ibu Baiq Lian Krisna Yutarti. Semua kepada desa dan lurah tersebut diangkat dan dilantik oleh Bupati Lombok Timur. Masing-masing desa dan kelurahan memiliki luas wilayah yang berbeda. Desa Rarang Batas memiliki wilayah 3,5 $\mathrm{Km}^{2}$, Desa Labuhan Lombok memiliki wilayah 4,2 $\mathrm{Km}^{2}$, Desa Dadap memiliki wilayah $4,6 \mathrm{Km}^{2}$, dan Kelurahan Selong memiliki wilayah 2,98 $\mathrm{Km}^{2}$.

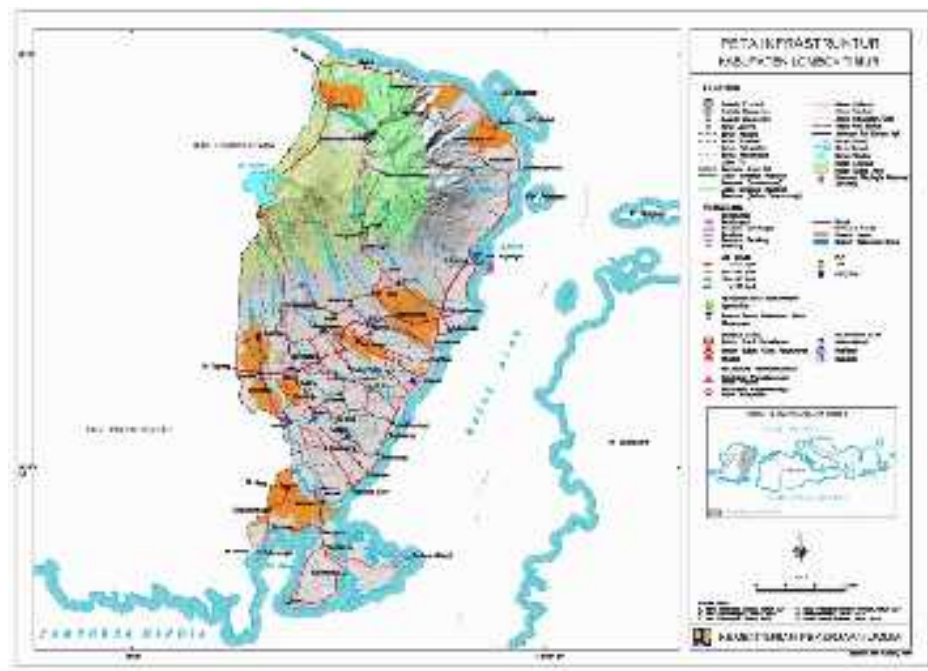

Gambar 1: Peta Wilayah Kabupaten Lombok Timur (Dokumentasi Kantor Kelurahan Selong 2018)

Kepemimpinan kepala desa dan lurah perempuan dapat dilihat dari kinerjanya, jika kinerjanya bagus maka kepemimpinannya bagus, tetapi jika kinerjanya kurang maka kepemimpinannya kurang bagus juga. Kinerja merupakan gambaran mengenai tingkat pencapaian pelaksanaan suatu kegiatan, program, kebijakan dalam mewujudkan sasaran, tujuan, misi dan visi organisasi (Arianto, 2013; Hasibuan \& Silvya, 2019; Ratnasari et al., 2019; Ruky, 2002; Suryani \& FoEh, 2018). Kinerja pegawai dapat dikatakan baik dapat dinilai dari beberapa kriteria; kesetiaan, prestasi kerja, kedisiplinan, kreativitas, kerjasama kecakapan dan bertanggung jawab.(Hasibuan \& Silvya, 2019). Berikut kinerja ibu Kepala Desa berdasarkan kriteria kesetiaan, prestasi, kedisiplinanm kreatifitas, kerjasama, kecakapan, dan tanggung jawab.

\section{Kesetiaan}

Setiap pemimpin tentu harus selalu konsisten terhadap tugas dan kewajiban menjadi seorang pemimpin, harus menjalankan tugas-tugas yang diamanahkannya, namun tidak semuapemimpin yang setia terhadap tugastugasnya menjadi seorang pemimpin tetapi tidak semua pemimpin yang mengabaikan tugasnya. Seperti ibu Kepala Desa yang selalu setia terhadap tugas 
dan pekerjaanya, Ibu Kepala Desa sangat setia menjalankan tugasnya seperti selalu mengontrol masyarakatnya ketika ada kegiatan-kegiatan baik yang diadakan di kantor maupun di lingkungan. Ketika ada program posyandu ibu Kepala Desa dengan senang hati hadir untuk menyaksikannya, di samping itu ketika diadakan gotong royong, ibu Kepala Desa juga ikut berpartisipasi dan ketika pembagian raskin. Hal tersebut sangat wajar yang dilakukan oleh seorang pemimpin terutama ibu Kepala Desa. Berikut keterangan staf yang bernama Mariyun umur 29th:

"Kinerja ibu Kepala Desa bagus, kalau dilihat dari kesetiaan beliau melayani masyarakatnya, beliau juga tidak pernah lari dari tugas-tugasnya, baik di kantor maupun di Desa ketika ada program-program dijalankan beliau pasti hadir untuk menemani dan mengontrol masyarakat. Ketika ada kegiatan sosial seperti gotong royong, posyandu. Selain beliau setia menyelesaikan tugas-tugasnya beliau juga aktif mengontrol masyarakatnya"(Wawancara Rarang September 2018).

Dari paparan wawancara di atas dapat dijelaskan kinerja ibu Kepala Desa dilihat dari kesetian beliau merupakan kinerja bagus karena setia melayani masyarakat dan mengontrol masyarakatnya ketika menjalankan program-program dan setia dalam menjalankan tugas-tugasnya sebagai patutnya seorang pemimpin.

\section{Prestasi}

Seorang pemimpin dikatakan bagus kinerjanya tentu harus memiliki prestasi selama menjabat, Karena dengan prestasi tersebut kita dapat mengukur kinerjanya. Tidak jarang pemimpin yang memiliki kemampuan dan prestasi dalam memimpin seperti kepemimpinan ibu Kepala Desa. Selama ibu Kepala Desa memimpin di Desa Kabupaten Lombok Timur, ibu Kepala Desa berhasil menjadikan Desa Kabupaten Lombok Timur mendapatkan berbagai penghargaan melalui lomba Desa berikut prestasi yang diraih kelurahan selama dipimpin oleh ibu Kepala Desa dipaparkan dalam wawancara dengan ibu Kepala Desa:

"Prestasi yang diraih oleh kelurahan selama saya memimpin yang pertama, kantor Lurah Selong mendapatkan penghargaan atas menang lomba Desa tingkat provinsi juara tiga 2017, yang kedua menang lomba lingkungan bersih sehat juara 1 tingkat kabupaten Lombok timur, yang ketiga 2018 juara 1 dalam lomba kebersihan kantor se-kabupaten Lombok Timur" (wawancara Selong, September 2018).

Dalam paparan wawancara ibu Kepala Desa di atas atas prestasi yang diraihnya selama beliau memimpin di Desa Kabupaten Lombok Timur, dalam wawancara tersebut dapat dijelaskan berikut prestasi yang diraih oleh ibu Kepala Desa selama memimpin di Desa Kabupaten Lombok Timur; 1). Juara tiga lomba Desa tingkat provinsi pada tahun 2018, 2).Juara satu lomba lingkungan bersih sehat pada tahun 2017 tingkat kabupaten. 3). Juara Satu Lomba kebersihan kantor tingkat kabupaten tahun 2018.

\section{Kedisiplinan}

Kedisiplinan merupakan hal yang harus ada pada setiap pejabat maupun pegawai terutama pemimpin. Karena kedisiplinan akan menghasilkan kinerja yang bagus, tentu tidak semua pemimpin yang disiplin namun tidak jarang 
pemimpin yang aktif dan disiplin baik dari berbagai bidang seperti. Disiplin datang tepat waktu, tidak pernah menunda-nunda tugasnya, mentaati aturanaturan yang ada.Berikut pernyataan seorang staf yang bernama Nukman 39th:

"Menurut saya, kinerja ibu Kepala Desa bagus, Kalau dilihat dari sikap perilaku ibu Kepala Desa orangnya disiplin, bertanggung jawab dan tidak mau menunda-nunda tugasnya, kalau ada tugas beliau segera mengerjakan, dan setiap program berjalan sesuai dengan target yang ditargetkan. Kami juga sebagai staf dibantu jika ada tugas yang belum selesai, biar tidak terhambat. Kalau dilihat dari pelayanan, kami dan beliau selalu berusaha untuk memberikan pelayanan yang terbaik bagi masyarakat kami" (wawancara Dadap September 2018).

Dari paparan di atas yang diungkapkan oleh salah seorang staf Desa Dadap dapat dijelaskan bahwa, kinerja ibu Kepala Desa bagus, jika dilihat dari sikap dan perilakunya. Ibu Kepala Desa merupakan pemimpin yang bertanggung jawab dari tugas-tugasnya dan tidak pernah menunda-nunda. Beliau juga orang yang disiplin dan menjalankan program sesuai dengan yang ditargetkan. Jadi menurut seorang staf kinerja ibu Kepala Desa bagus. Sama halnya yang disampaikan oleh seorang staf Desa Labuhan Lombok yang bernama Nurrohman umur 32th mengenai kedisiplinan ibu Kepala Desa berikut wawancara;

"Ibu Kepala Desa orangnya disiplin, datang tepat waktu, kalau beliau berhalangan masuk kantor terlebih dahulu beliau nelpon atau memberikan pemberitahuan terhadap kami selaku bawahannya, beliau juga sopan taat aturan, meskipun beliau perempuan namun beliau sangat menghargai tugas-tugas beliau, sehingga program yang diprogramkan berjalan sesuai dengan target" (wawancara Labuhan Lombok September 2018).

Dari pemaparan di atas dapat dijelaskan mengenai kedisiplinan ibu Kepala Desa, yang selalu hadir pada tepat waktu dan selalu menghargai tugas-tugasnya sebagai Kepala Desa.

\section{Kreativitas}

Setiap orang mempunyai kreatifitas masing-masing sesuai dengan bidang masing-masing namun tidak semua orang bisa mengembangkan ide-ide dan gagasannya untuk merealisasikan terhadap masyarakat. Namun tidak sedikit orang mengembangkan ide-ide atau kreatifitasnya untuk kelancaran yang digelutinya. Terlebih-lebih seorang pemimpin harus mempunyai kreatifitas dalam mensejahterakan masyarakat yang dipimpinnya terutama memanfaatkan potensi yang ada di daerah atau tempat masing-masing, seperti memberikan pelatihan, sosialisasi, untuk memberikan kesejahteraan bagi rakyatnya, seperti halnya yang dilakukan oleh ibu Kepala Desa.

Kreatifitas yang beliau punya yaitu mengajarkan masyarakat tentang pentingnya hidup sehat dan pentingnya bersih lingkungan. Jadi disamping untuk menyadarkan masyarakat tentang pentingnya hidup sehat juga bisa memberikan dampak agar visi misi tersebut bisa dijalankan. Berikut wawancara dengan ibu Kepala Desa mengenai kreativitas;

"Mengenai kreativitas menurut saya, memiliki cara tersendiri, salah satunya untuk menjalankan hidup bersih kami dan para staf melakukan sosialisasi tentang hidup sehat, kami juga memfasilitasi organisasi perempuan seperti, PKK, LPP, Dasa Wisma. Pembuatan kue bintang 
surya. Alhamdulilah saya juga pernah bekerja,di kantor-kantor jadi sedikit tidak pengalaman,ide-ide itu dapat saya salurkan disini" (wawancara Rarang, September 2018).

Menurut keterangan ibu Kepala Desa kreativitas itu memiliki cara tersendiri bisa berupa bentuk fisik, maupun pemikiran atau iide-ide yang dikembangkan oleh seseorang.

\section{Kerjasama}

Membangun kerjasama merupakan hal yang harus dilakukan oleh seorang pegawai atau pejabat untuk kelancaran tujuan yang ingin dicapainya, tentu membangun kerjasama harus dengan interaksi yang baik terhadap sesama pegawainya atau sesama pejabat.Terlebih yang harus dilakukan oleh seorang pemimpin terhadap bawahannya, saling membantu dalam menyelesaikan tugastugasnya. Seperti yang dilakukan oleh ibu Lurah. Berikut pernyataan seorang Staf kelurahan Selong yang bernama H. Rubai umur 41th;

"Dalam membangun kerjasama beliau dengan kami selalu saling membantu, jika kami belum menyelesaikan tugas-tugas yang harus diselesaikan beliau membantu kami, begitu juga jika beliau dalam keadaan kurang sehat kami juga membantu, setiap ada program yang akan diselenggarakan beliau melakukan rapat bersama kami dan saling memberikan pendapat guna untuk terlaksana program tersebut, saling memotivasi dan saling mendukung dalam menjalankan tugas-tugas dan perlakuan beliau sangat baik terhadap kami" (wawancara Selong, September 2018).

Berdasarkan hasil wawancara di atas dapat dijelaskan mengenai kerjasama ibu Lurah dengan bawahannya yang selalu saling bantu, dalam menjalankan tugas-tugasnya.menjalin hubungan yang baik terhadap bawahannya, sehingga dapat terbentuk kerjasama yang baik antara pimpinan dengan bawahannya guna untuk kelancaran tugas-tugas atau program-program yang dijalankannya.

\section{Kecakapan}

Kecakapan seorang pemimpin tentu dibentuk oleh pengalaman dan pendidikan yang pernah ditempuhnya. Seorang pemimpin tentu harus memiliki ilmu pengetahuan atau memiliki skill, guna untuk memajukan yang dipimpinya. Tidak semua pemimpin memiliki pengalam atau ilmu pengetahuan dalam memimpin.Tetapi banyak pemimpin yang menyiapkan dirinya sebelum menjadi pemimpin, sehingga kecakapan dirinya sebagai pemimpin telah ada. Mengenai kecakapan ibu lurah sebagai pemimpin di Kelurahan Selong, berikut pernyatan Kepala Seksi Pemberdayaan dan Kesejahteraan Masyarakat yang bernama Yuhanun, umur 40 tahun :

"Mengenai kecakapan beliau, menjadi pemimpin saya rasa cocok karena beliau sudah pengalaman bekerja dalam pemerintahan beliau selalu berusaha memperbaiki dan menambah apa yang masih dirasakan kurang, untuk terwujud kelancarannya aktivitas dan keberhasilannya di kantor dalam melayani masyarakat beliau pernah bekerja di kantor Desa Sandubaya, beliau juga pernah menimba ilmu pengetahuan di IPDN jadi saya rasa beliau punya pengalaman dalam memimpin" (wawancara Selong,September 2018). 
Dalam pernyataan pegawai kantor kelurahan Selong dapat digambarkan mengenai kinerja lurah perempuan, kinerja ibu lurah bagus, jika dilihat dari kecakapan dan pengalaman yang beliau miliki. Beliau juga memiliki sifat murah senyum, ramah, pengertian dan memiliki sifat partisipasi yang tinggi dan terbuka terhadap seluruh jajaran aparaturnya selain itu, ibu Kepala Desa juga memiliki pengalaman pernah bekerja di kelurahan Sandubaya, selain itu beliau juga pernah menimba ilmu pengetahuan di Institut Pemerintah Dalam Negeri (IPDN). Jadi disamping memiliki pengalaman dalam bekerja juga memiliki ilmu pengetahuan dalam hal memimpin. Kecakapan dalam memimpin juga diukur melalui pengalaman dalam bekerja atau riwayat pekerjaan yang pernah ditempuh atau yang dilalui sebelum menjabat. Ibu lurah sebelum menjabat menjadi lurah di Selong, sebelumnya itu memiliki pengalaman. Berikut pemaparan wawancara ibu Lurah yang dilakukan peneliti ;

"Sebelum saya menjabat menjadi Kepala Desa, saya juga pernah bekerja di kantor-kantor seperti, 2005-2008 saya menjabat sebagai kasi kasra pemerintah di Desakembang Sari, 2008-2009 menjadi Lurah di Kelurahan Sandubaya, 2009-2010 sebagai bidang keuangan di dinas pariwisata, 20102011 menjabat sebagai bagian keuangan di APBD lombok timur, 20112015 bekerja di kecamatan Selongv,2016 sampai sekarang menjadi Lurah di Selong". (Wawancara Selong, September 2018).Dari paparan wawancara tersebut dapat dijelaskan mengenai pengalaman bekerja, ibu lurah . Jadi beliau sudah pengalaman dalam bekerja.

\section{Tanggung jawab}

Setiap orang memiliki tugas dan tanggung jawab masing-masing untuk menjalankan kehidupan sehari-hari, terlebih-lebih seorang pemimpin, seorang pemimpin harus bertanggung jawab terhadap bawahannya, tugas dan kewajibannya harus dilaksanakan. Terutama program-program yang disusun harus dilaksanakan sesuai dengan target yang ditentukan. Menurut keterangan mengenai kinerja ibu kepala desa, kinerjanya bagus dan bertanggung jawab. Berikut pernyataan masyarakat dalam wawancara dengan masyarakat Labuhan Lombok yang bernama Muhidin 23 tahun:

"Kinerjanya ibu kepala desa bagus dan orangnya bertanggung jawab di samping itu juga infrastrukturnya lebih bagus, yang dulu itu masih kurang, jadi sekarang bagus, lingkungannya juga bersih, ya yang namanya pemimpin beda-beda, tetapi sekarang Kepala Desanya kinerjanya

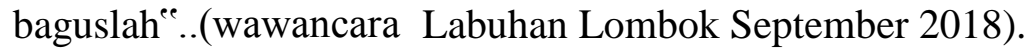

Berdasarkan pemaparan di atas dapat dijelaskan bahwa Menurut keterangan masyarakat kinerja kepala desa perempuan bagus, dan bertanggung jawab terhadap tugas-tugasnya sehingga, ketika beliau melakukan program terlaksana dengan baik. Sebelum ibu kepala desa menjabat pembangunan belum merata, seperti infrastruktur yang ada di desa masih belum sepenuhnya diperbaiki dan lingkungan-lingkungan di desa Labuhan Lombok Timur masih belum tertata rapi dan belum bersih. Semenjak ibu kepala desa menjabat tahap demi tahap ada perubahan baik dari segi pelayanan maupun dari segi pembangunan. Keterangan 
ini peneliti dapatkan pada waktu peneliti mewawancarai salah satu, masyarakat Desa Dadapyang bernama Supriadi umur 30 tahun :

“Kinerja ibu kepala desa Dadap bagus, beliau orangnya bertanggung jawab apa yang belum tuntas beliau tuntaskan dan dari segi pembangunan, lebih merata dibandingkan dengan kepala desa yang sebelumnya, seperti diperbaiki jalan di gang-gang, irigasi, membuat gapura tiap RT, dan terselenggaranya program bantuan bedah rumah bagi masyarakat kurang mampu atau rumah tak layak huni,dan beliau juga sering memberikan sosialisasi kepada masyarakat tentang hidup bersih. Iya ada perubahanlah dari yang sebelumnya" (wawancara Dadap, September2018.)

Dari keterangan yang diungkapkan oleh narasumber di atas dapat dijelaskan bahwa, kinerja kepala desa perempuan yang lebih ada perubahan dari kepemimpinan kepala desa yang sebelumnya. Hal tersebut dapat dilihat dari pemerataan pembangunan yang dilakukan oleh ibu kepala desa.

\section{Persepsi Masyarakat Terhadap Kinerja Kepala Desa Perempuan Di Desa Kabupaten Lombok Timur}

Persepsi mempunyai banyak pengertian, diantaranya adalah persepsi merupakan kesan yang diperoleh oleh individu melalui panca indra, kemudian dievaluasi sehingga individu tersebut memperoleh makna. Kinerja ibu kepala desa jika dibandingkan dengan yang sebelumnya jauh lebih bagus kinerja kepala desa yang sekarang dilihat dari pembangunan yang sebelumnya belum sepenuhnya rampung. Sekarang lingkungan kelurahan Selong menjadi lebih bersih. Dilihat dari infrastruktur, jauh lebih bagus dari yang sebelumnya. Berikut paparan wawancara yang dilakukan oleh salah seorang tokoh agama di Selong yang bernama H. Muslim, QH Sos.I umur 50 tahun :

"Menurut pengamatan saya selama ibu Lurah memimpin, mengenai kinerja ibu lurah, kinerjanya bagus, Saya setuju dipimpin lurah perempuan karena banyak sekali perubahan yang kami rasakan terutama kebersihan lingkungan, dan kinerjanya bagus dilihat dari pembangunannya, jika dibandingkan dengan lurah yang sebelumnya, sedikit ada perubahan. Dahulukan belum ada gapura-gapura tiap RT, sekarang ada, terus penataan jalan di lingkungan, dulu tidak semuanya bagus tapi sekarang bagus, dan banyak juga program-program yang saya rasa bagus yang telah beliau laksanakan" (wawancara Selong,September 2018).

Hal tersebut di atas menggambarkan bahwa kinerja ibu lurah menurut salah seorang tokoh agama di Selong merupakan kinerja bagus, jika dibandingkan dengan kinerja Kepala Desa sebelumnya jauh lebih baik dari yang sekarang, pembangunan yang dulu terhambat menjadi terselenggara atau bisa diselesaikan oleh ibu lurah. Sekarang kelurahan Selong mengalami kemajuan dari segi pembangunan yang sebelumnya infrastruktur yang rusak diperbaiki dan menjadikan Selong menjadi bersih dan tertata rapi.

Untuk melihat kinerja seorang pejabat bukan hanya diukur atau dilihat dari pembangunan, namun dilihat juga dari sistem pelayanan yang diberikan kepada masyarakat. Sistem pelayananan di desa-desa maupun di kota perlu ditingkatkan 
karena pelayanan merupakan pokok utama dalam membantu masyarakat, namun tidak semua pelayanan di instansi pemerintahan pelayanan dengan melayani baik. Ada sebagian juga instansi pemerintahan yang berupaya meningkatkan pelayanan bagi masyarakat guna memberikan kesejahteraan bagi masyarakat. Salah seorang tokoh masyarakat desa Rarang menilai kinerja ibu kepala desa dari segi pelayanan, menurutnya kinerja ibu kepala desa termasuk kinerja yang bagus jika dilihat dari sistem pelayanan. Berikut pernyataan salah seorang tokoh masyarakat yang bernama Mahdi umur 59 tahun dalam wawancara yang dilakukan peneliti :

"Kinerja ibu kepala desa bagus, seperti yang kami rasakan perubahan, jika dilihat dari pelayanannya bagus dalam melayani masyarakat, dari segi pembangunannya juga bagus, ada perkembangannya. Dulu pembangunannya belum merata banyak yang belum diselesaikan tetapi semenjak beliau menjabat alhamdulilah pembangunannya lancar, beliau juga selalu mengajak masyarakat untuk sama-sama gotong royong dalam membersihkan lingkungan bersama kepala lingkungan. Melihat dari kinerjanya yang bagus, saya setuju dipimpin beliau meskipun pemimpinnya perempuan".(wawancara Rarang, September 2018).

Berdasarkan pemaparan di atas, dapat dijelaskan mengenai kinerja ibu kepala desa menurut tokoh masyarakat di desa Rarang. Menurut keterangan beliau kinerja ibu kepala desa bagus, jika dilihat dari sistem pelayanannya dan partisipasi ibu kepala desa dalam mengajak masyarakat untuk membersihkan lingkungan beliau orangnya merakyat. Jadi kinerja ibu Kepala Desa bagus dalam membantu masyarakat dari segi pelayanannya dan tokoh masyarakat tersebut setuju dipimpin oleh ibu kepala desa. Hal yang sama juga diungkapkan oleh salah seorang tokoh Adat yang berada di Desa Labuhan Lombok mengenai kinerja kepala desa perempuan. Berikut pemaparan tokoh adat yang bernama H. L. Usman umur 50 tahun :

"Kalau yang saya lihat Kinerja ibu kepala desa bagus, meskipun beliau perempuan tetapi orangnya tegas dalam menyikapi permasalahan, semenjak beliau menjabat sebagai kepala desa di desa Labuhan Lombok semakin maju, sedikit ada perubahan dalam penataan lingkungan, saya setuju melihat beliau menjadi pimpinan di desa Labuhan Lombok" (Wawancara Labuhan Lombok, September 2018).

Dari pernyataan di atas dapat dijelaskan mengenai kinerja ibu kepala desa menurut keterangan dari salah seorang tokoh adat kinerja ibu kepala desa bagus meskipun ibu kepala desa perempuan namun kinerjanya tidak kalah dengan kinerja pemimpin laki-laki, ibu kepala desa selalu memperbaiki apa yang belum selesai dikerjakan oleh kepala desa yang sebelumnya. Beliau juga selalu memperhatikan keadaan masyarakatnya.

Dalam melihat kinerja seorang pemimpin tidak terlepas dari sikap dan perilakunya, tidak semua pemimpin yang bisa berperilaku baik terhadap bawahannya. Namun sebagian pemimpin mampu berinteraksi dengan baik terhadap bawahannya. Menurut keterangan mengenai kinerja ibu kepala desa yang bagus dan bertanggung jawab, Berikut pernyataan salah satu kepala lingkungan di desa Rarang yang bernama Nasirudin berumur 40 tahun: 
"Kinerjanya bagus dan orangnya bertanggung jawab di samping itu juga infrastrukturnya lebih bagus, beliau juga berinteraksi dengan baik dengan kami selaku kepala lingkungan, kalau ada program yang akan dilaksanakan di lingkungan kami, beliau berkoordinasi terlebih dahulu atau memberikan informasi, ya yang namanya pemimpin beda-beda, tetapi sekarang Kepala Desanya kinerjanya baguslah" (Wawancara Rarang, September 2018).

Berdasarkan pemaparan di atas dapat dijelaskan bahwa kinerja kepala desa perempuan bagus, dan bertanggung jawab terhadap tugas-tugasnya. Sehingga, ketika beliau melakukan program terlaksana dengan baik. Beliau juga berinteraksi dengan baik terhadap kepala lingkungan, jika akan mengadakan program di lingkungan terlebih dahulu menyampaikan kepada kepala lingkungan setempat.

Kepala desa perempuan juga menjadikan desa Dadap menjadi semakin maju dari sebelumnya. Ketika dipimpin kepala desa perempuan infrastruktur menjadi bagus dan lingkungan menjadi bersih. Keamanan terjaga kondusif dengan didirikan pos-pos ronda di tiap-tiap lingkungan. Masyarakat selalu melihat dan menilai pemimpinnya, sehingga seorang pemimpin harus bisa memberikan yang terbaik bagi masyarakatnya. Berikut pemaparan hasil wawancara dengan salah seorang masyarakat desa Dadap yang bernama H.M. Amrullah 40 th:

"Saya sangat setuju dipimpin oleh perempuan, karena kita butuhkan kemajuan semasih bisa memimpin tidak apa-apa di pimpin perempuan, semasih dia bisa adil, jujur, amanah, dan melayani masyarakat dengan baik, juga kalau perempuan lebih ramah. Terlebih kepala desa perempuan ibu Lian ini selama kepemimpinannya bagus, jadi saya sangat setuju"(Wawancara Dadap, September 2018).

Berdasarkan hasil wawancara yang dipaparkan di atas dapat dijelaskan mengenai pendapat masyarakat tentang pemimpin perempuan. Masyarakat sangat setuju dipimpin kepala desa perempuan mereka beranggapan bahwa pemimpin perempuan itu lebih ramah dan transparan dalam memberikan informasi sehingga masyarakat sangat setuju dipimpin kepala desa perempuan. Mereka juga beranggapan kalau pemimpin perempuan itu lebih disiplin dan jujur dalam menjalankan tugas-tugasnya. Perempuan lebih terbuka dalam menyampaikan sesuatu, lebih sopan, lemah lembut dan tegas. Dalam melihat pemimpin itu bagus atau tidaknya dilihat dari perubahan atau kemajuan yang dipimpinnya, apakah mengalami kemajuan atau kemunduran. Berikut pemaparan hasil wawancara dengan salah seorang tokoh pemuda Selong yang bernama Rusman 28 th:

"menurut penilaian saya kinerja lurah perempuan, bagus sama halnya dengan lurah yang lain, dari segi perubahan saat beliau menjabat biasa-biasa saja kalau menurut saya, tetapi dari segi kebersihan lingkungan jauh lebih bersih sekarang, kalau dulu banyak sampah yang berserakan di mana-mana di sekitaran Selong(Wawancara Selong, September 2018.) 
Berdasarkan pemaparan di atas dapat dijelaskan pendapat salah seorang pemuda mengenai kinerja kepala desa dan lurah perempuan, perubahan yang terjadi ketika dipimpin kepala desa dan lurah perempuan menurut keteranganya pemuda tersebut menilai kinerja kepala desa/lurah perempuan, kinerjanya bagus sama halnya dengan pemimpin yang lain hanya saja perubahan yaitu dari kebersihan lingkungan di desa yang dulunya kurang bersih tetapi sekarang terlihat bersih.

\section{Tantangan dan Hambatan Kepala Desa Perempuan Dalam Menjalankan Tugas-Tugasnya}

Tantangan dapat diartikan sebagai sesuatu yang membuat sulit, kadang menghambat sesuatu yang ingin kita capai. Begitu pula dengan kepemimpinan kepala desa dalam menjalankan tugas dan tanggung jawabnya tidak lepas dari sebuah tantangan. Setiap pemimpin pasti memiliki tantangan dan hambatan seperti kepemimpinan ibu kepala desa/lurah. Tidak bisa dipungkiri status juga menjadi halangan, antara laki-laki dan perempuan sudah diberikan tugas sesuai dengan kemampuan yang dimilikinya. Mengenai tantangan dan hambatan kepala desa/lurah perempuan dalam menjalankan tugas-tugasnya. Berikut pernyataan ibu Kepala Desa Labuhan Lombok dalam wawancara:

"Tantangan saya yaitu disamping saya menjadi Kepala Desa saya juga harus mengurus anak dan suami saya sehingga terasa berat namun karena itu sudah kewajiban saya, jadi harus bisa membagi waktu agar dua-duanya terurus. Hambatan yang saya alami, saya perempuan, jadi gerak saya terbatas, ketika bekerja malam hari jika saya dibutuhkan/ kegiatan pada malam hari tentu jamnya saya batasi sampai jam yang semestinya, disamping itu yang menjadi hambatan saya yaitu ketika anak saya sakit, ketika ada permasalahan di lingkungan pada malam hari terlebih-lebih hujan jadi saya tidak tega untuk meninggalkan sehingga saya menyuruh staf saya untuk mewakili ( Juni 2018)."

Berdasarkan wawancara di atas dapat dijelaskan mengenai tantangan dan hambatan ibu kepala desa dalam menjalankan tugas-tugasnya sebagai seorang pemimpin.

Berikut tantangan dan hambatan yang dihadapi seorang kepala desa/lurah perempuan dalam menjalankan tugas- tugasnya:

\section{- Membagi waktu tugas sebagai pimpinan dan tugas sebagai ibu rumah tangga}

Ibu kepala desa/lurah harus pandai dalam membagi waktu, antara tanggung jawabnya sebagai kepala desa/lurah dan tanggung jawabnya menjadi ibu rumah tangga sehingga dituntut untuk bekerja ekstra dalam menjalankan tugas dan kewajibannya. Ibu kepala desa/lurah harus bisa mengurus tugas-tugasnya, sehingga ibu kepala desa harus memaksimalkan waktunya dengan sebaikbaiknya, agar tugasnya tidak terabaikan.

\section{- Waktu terbatas dalam melayani masyarakat pada malam hari}

Ibu kepala desa/lurah membatasi waktu pelayanan pada malam hari, karena beliau seorang perempuan, tentu tidak bebas keluar pada malam hari untuk melayani masyarakat, beliau harus membatasi waktunya ,karena seorang 
perempuan tidak baik keluar rumah sampai larut malam. Sehingga tidak sepenuhnya melayani masyarakat pada malam hari. Hal tersebut sudah wajar meskipun beliau seorang pemimpin namun beliau tidak bisa mengingkari kodratnya sebagai seorang perempuan yang harus menjaga etika dan kesopanan.

\section{- Menjaga kondisi kesehatan anak dan keluarga}

Ketika suami atau anak ibu kepala desa/lurah sedang sakit tentu beliau tidak tega untuk meninggalkan di rumah sehingga beliau lebih memilih menjaga keluarga atau anaknya dan memerintahkan bawahannya untuk mewakilinya. Ibu kepala desa/lurah tidak bisa melaksanakan tugas beliau ketika anak beliau kurang sehat, sehingga ketika ada permasalah di lingkungan desa atau kelurahan yg dipimpinnya, beliau tidak bisa menghadirinya. Hal tersebut merupakan hambatan yang dialami oleh seorang kepala desa/lurah perempuan selama beliau memimpin di wilayahnya.

\section{ANALISA TEORI DAN TEMUAN}

Dalam buku mereka "The Social Construction of Reality", Berger dan Thomas Lukcman mengembangkan teori sosiologi: "Masyarakat adalah realitas objektif dan realitas subjektif." Dia menganalisis masyarakat sebagai realitas subjektif dan menjelaskan bahwa persepsi seseorang tentang realitas adalah proses di mana mereka berinteraksi dengan masyarakat. Ia berbicara tentang bagaimana konsep atau penemuan manusia baru terus menjadi bagian dari realitas manusia itu sendiri, yang ia sebut sebagai proses objektifikasi. Dalam proses selanjutnya, realitas ini tidak lagi dilihat sebagai ciptaan manusia melalui proses yang disebut Berger internalisasi. Realitas objektif berarti pelembagaan itu. Dipahami secara utuh kemudian menjelma menjadi adiksi (kecanduan). Ini secara langsung mengarah pada pengendapan dan tradisi. Pengendapan dan tradisi ini kemudian diwariskan kepada generasi berikutnya melalui bahasa. Tatanan kelembagaan berperan di sini, dan juga terkait dengan tradisi dan warisan pengalaman. Jadi peran adalah semacam tatanan institusional, atau lebih jelas, persepsi peran adalah ekspresi diri. (Berger, 1991). Dalam hal ini peranan yang dapat dipandang mempresentasikan suatu keseluruhan rangkaian perilaku yang melembaga, misalnya peranan Ibu Kepala Desa Kabupaten Lombok Timur tersebut dengan peran-peran lainnya di sektor pemerintahan desa/ kota dan pemerintahan daerah dalam menjalankan tugas sebagai sosok perempuan yang memimpin sebuah wilayah perkotaan.

Dalam hal ini, legitimasi/teori dibuat untuk melegitimasi organisasi sosial.Proses "legitimasi sebagai legitimasi lembaga sosial" menuju "lembaga sosial sebagai penjaga legitimasi" terus berlangsung dan dialektik. Dialektika ini terus terjadi, dan dialektika ini yang berdampak pada perubahan sosial (Berger, 1991). Dalam kasus yang ditemukan dalam penelitian ini nampak jelas dalam konsep masyarakat sebagai sebuah realitas obyektif dengan kata kuncinya terdapat dan terciptanya legitimasi dalam menjaga universum yang ada yakni dalam hal penegakan universum pemerintah dalam diri seorang Kepala Desa sebagai penjaga dan pelaksana dari legitimasi negara yang berdaulat yang dalam kasus ini Kepala Desa Kabupaten Lombok Timur dengan jenis kelamin perempuan. Dimana dalam prakteknya legitimasi tersebut saling berhadap-hadapan dengan harmonisasi perubahan sosial yang dinamis dalam tubuh masyarakat Kota Kabupaten Lombok Timur Kabupaten Lombok Timur. 
Menganggap masyarakat sebagai realitas subjektif berarti realitas objektif dijelaskan secara subjektif oleh individu. Internalisasi terjadi dalam proses interpretasi. Internalisasi adalah proses yang dilalui manusia dalam rangka mengambil alih dunia di mana masing-masing hidup. Internalisasi berlangsung seumur hidup, termasuk sosialisasi primer dan sekunder. Internalisasi adalah proses menerima definisi orang lain tentang dunia institusional. Setelah menerima definisi ini, individu hanya dapat memahami definisi orang lain, tetapi yang lebih penting, mereka juga dapat membantu membangun definisi bersama. Dalam proses mengkonstruksi ini, individu berperan aktif dalam membentuk, memelihara dan mengubah masyarakat.(Berger, 1991). Dalam hal ini peranan yang telah dijalankan oleh Kepala Desa Kabupaten Lombok Timur dalam membentuk dan memelihara keteraturan dengan proses sosialisasi dan kinerja yang ditunjukkan dengan berbagai prestasi sebagai pimpinan wilayah, sehingga dalam hal ini kemampuan internalisasi masyarakat kota Kabupaten Lombok Timur baik secara primer dan sekunder sosok Kepala Desa Kabupaten Lombok Timur tersebut termasuk dalam kategori berhasil. Hal ini dapat diukur dan mendapat pembenaran dari warga masyarakat kota Kabupaten Lombok Timur yang setuju dan merasakan berbagai macam bentuk perubahan kearah yang baik dalam segi pembangunan fisik dan pembangunan kualitas hidup manusianya.

\section{Relevansi Teori Konstruksi Berger terhadap Perubahan Sosial yang terjadi sampai saat ini}

Realitas objektif dan realitas subjektif Berger adalah realitas yang terjadi dalam masyarakat itu sendiri. Seperti yang dikatakan Berger dan Durkheim, struktur sosial objektif memiliki ciri-ciri sebagai berikut: 1. Eksternalisasi (eksternal) adalah upaya mengaktifkan atau mengada (person) di dunia luar, yang salah satunya didasarkan pada kebutuhan. Atau proses dimana manusia menciptakan sesuatu. 2. Objectify, usahakan untuk menampung objek tersebut agar tidak sia-sia dan tidak akan musnah. 3. Internalisasi (dalam). Asimilasi nilai atau norma manusia (Berger, 1991).

Sederhananya, teori Berger adalah tentang membangun masyarakat, dengan kata lain, tentang membangun masyarakat. Sejauh menyangkut pembangunan itu sendiri, paradigma kita tentu memahami bahwa akan ada perubahan sosial, karena pembangunan itu sendiri akan membawa perubahan sosial, apakah itu fungsional, disfungsional, baik atau buruk. Dalam teorinya, Berger menyinggung penemuanpenemuan baru, yang secara terus menerus menjadi bagian dari realitas manusia itu sendiri, dan penemuan-penemuan baru cepat atau lambat akan membawa perubahan sosial. Sehingga dapatr disimpulkan berdasarkan temuan dalam kajian ini bahwa teori berger tersebut sejalan dengan kondisi yang dialami oleh masyarakat Kabupaten Lombok Timur dan oleh Kepala Desa perempuan kota Kabupaten Lombok Timur baik secara internalisasi dan eksternalisasinya dalam upaya pemajuan kualitas hidup masyarakatnya.

\section{SIMPULAN}

\section{Kinerja Kepala Desa/Lurah Perempuan}

Berdasarkan hasil penelitian maka dapat disimpulkan bahwa kinerja kepala desa/lurah perempuan di Kabupaten Lombok Timur, dinilai kinerjanya bagus, bertanggung jawab, disiplin dan tidak pernah menunda-nunda dalam menjalankan 
tugas-tugasnya. Serta pemerataan pembangunan yang terus-menerus dilaksanakan sesuai dengan program-program yang telah dijalankan. Hal ini diakui oleh beberapa staf desa dan masyarakat Kabupaten Lombok Timur.

\section{Persepsi Masyarakat Terhadap Kinerja Kepala Desa/LurahPerempuan}

Kinerja kepala desa/lurah perempuan dianggap cukup bagus jika dibandingkan dengan kinerja kepala desa/lurah yang sebelumnya. Partisipasinya tinggi sering mengajak masyarakat dalam bergotong royong dan menjadikan wilayahnya lebih maju dari yang sebelumnya.

\section{Tantangan dan Hambatan Yang Dihadapi Kepala Desa/Lurah Perempuan}

Selain menjadi ibu rumah tangga mengurus anak-anak dan suaminya. Seorang pimpinan desa khususnya lurah juga menjadi Pegawai Negri Aparatur Sipil Negara harus bisa membagi waktu antara pekerjaan rumah tangga dengan pekerjaan dinasnya. Ketika suami atau anaknya sakit tidak bisa meninggalkannya di rumah. Jadi ketika dibutuhkan diwakili oleh sekretaris atau staf pegawai di kantornya.

\section{DAFTAR PUSTAKA}

Berger, P. L. (1991). Langit suci: Agama sebagai realitas sosial. LP3ES.

Davis, A. L., Allen, J., Shepler, L., Resick, C., Lee, J., Marinucci, R., \& Taylor, J. A. (2020). Moving FOCUS-The Fire Service Organizational Culture of Safety survey-From research to practice. Journal of Safety Research, 74, 233-247.

Davis, R., \& Cates, S. (2018). The Implementation Of The Organizational Culture Assessment Instrument In Creating A Successful Organizational Cultural Change. International Journal of Business \& Public Administration, 15(1).

Fitriani, A. (2015). Gaya kepemimpinan perempuan. Jurnal Tapis: Jurnal Teropong Aspirasi Politik Islam, 11(2), 1-22.

Frost, P. J., Moore, L. F., Louis, M. R. E., Lundberg, C. C., \& Martin, J. E. (1985). Organizational culture. Sage Publications, Inc.

Handriana, N., \& Basuki, B. D. (2012). Gaya Kepemimpinan Laki-Laki Dan Perempuan. Jurnal Ekonomi Dan Bisnis Airlangga (JEBA), 22(2).

Hasibuan, J. S., \& Silvya, B. (2019). Pengaruh Disiplin Kerja dan Motivasi Terhadap Kinerja Karyawan. Prosiding Seminar Nasional USM, 2(1), 134147.

Horner, M. (1997). Leadership theory: past, present and future. Team Performance Management: An International Journal.

Lussier, R. N., \& Achua, C. F. (2015). Leadership: Theory, application, \& skill development. Cengage learning.

Moleong, L. J. (2019). Metodologi penelitian kualitatif.

Murcahyanto, M. H., \& Asmawi, M. (2019). Effect Of Democratic Leadershipstyle, Organizational Culture On Lecturers' Performance. ICTES 20181 (EAI)

Nohria, N., \& Khurana, R. (2010). Handbook of leadership theory and practice. Harvard Business Press. 
Novianti, I. (2008). Dilema kepemimpinan perempuan dalam Islam. Yinyang: Jurnal Studi Islam Gender Dan Anak, 3(2), 255-261.

Pasolong, H. (2008). Kepemimpinan Birokrasi. Bandung: Alfabeta.

Purnomo, H., \& Subari, L. (2019). Manajemen Produksi Pergelaran: Peranan Leadership dalam Komunitas Seni Pertunjukan. JURNAL SATWIKA, 3(2), 111-124.

Ratnasari, S. L., SE, M. M., \& Hartati, Y. (2019). Manajemen Kinerja Dalam Organisasi. Penerbit Qiara Media.

Ruky, A. S. (2002). Sistem manajemen kinerja. Gramedia Pustaka Utama.

Sahrah, A. (2004). Persepsi terhadap Kepemimpinan Perempuan. Anima: Indo Psycho-Logical Journal, 19(3).

Situmorang, N. Z. (2011). Gaya kepemimpinan perempuan. Proceeding Pesat, 4.

Sugiono. (2017). Metode Penelitian Kuantitatif, Kualitatif dan R\&D. Penerbit Alfabeta.

Sugiyono, M. (2012). Metode Penelitian Kuantitatif $R \& D$. Alfabeta.

Suryani, N. K., \& FoEh, J. E. H. J. (2018). Kinerja Organisasi. Deepublish.

Underdal, A. (1994). Leadership theory. International Multilateral NegotiationApproaches to the Management of Complexity.-San Francisco, 178-197.

Van Seters, D. A., \& Field, R. H. G. (1990). The evolution of leadership theory. Journal of Organizational Change Management.

Way, C., Gregory, D., Davis, J., Baker, N., LeFort, S., Barrett, B., \& Parfrey, P. (2007). The impact of organizational culture on clinical managers' organizational commitment and turnover intentions. JONA: The Journal of Nursing Administration, 37(5), 235-242. 